\title{
Non-Invasive Lesion
}

National Cancer Institute

\section{Source}

National Cancer Institute. Non-Invasive Lesion. NCI Thesaurus. Code C36027.

A neoplastic process that is confined to the site of orig in without morphologic evidence of cellular infiltration of the surrounding tissues. 